\title{
PRIVATIZATION DYNAMICS AND THE STATE OF PROPERTY RELATIONSHIPS IN 2014: KEY TRENDS
}

\author{
G.Malginov, A.Radygin
}

The past year was the first year of implementing the Forecast plan (program) of federal property privatization and the guidelines of federal property privatization for 2014-2016. The privatization program implementation was seriously hampered by adverse trends which began to develop as recently as Q1 2014. Earlier in December last year, when the federal budget for 2015-2017 was adopted, budget revenues from federal property privatization were envisaged to run at Rb 158,5bn in 2015. However, the updated in April 2015 version of the federal budget provides for drastic cuts, up to $R b 15,0 b n$, of revenues from federal property privatization. A reduction by an order of magnitude in revenues from federal property privatization will make their role strictly supplementary in financing federal budget deficit compared to the suggested spending of the resources from the Reserve Fund.

The past year was marked by launching the Forecast plan (program) of federal property privatization and the guidelines of federal property privatization for 2014-2016 approved by the Russian Government Executive Order of 1 July 2013 No. 1111-p.

In 2014, the shares (shareholding in the chartered capitals) in a total of 108 business units (148 in 2013) were sold, and decisions on the terms of privatization were made with regard to 33 federal state unitary enterprises (FSUEs) (26 in 2013). The foregoing figures have been determined by the recently developed trends towards increasingly smaller number of sold blocks of shares (shareholding) and the unitary enterprises specified by the government orders for setting the terms of privatization. The amount of sold blocks of shares (shareholding) is less than that of those sold during the five previous years (2009-2013), except the crisis-hit 2009 (52 units), while the number of privatized FSUEs isn't bigger than that of the previous periods, except 2013.

The privatization program implementation was seriously affected by the adverse trends which began to develop as early as Q1 2014, but mostly manifested themselves by the end of the year (the massive capital outflow, the introduction of various mutual sanctions, the fall of global prices of energy resources, the weakening of the ruble's exchange rate, the chance of a recession in the Russian economy).

Naturally, the completed two largest privatization transactions were prepared as early as 2012-2013 and undertaken before adverse economic and political developments took place last year.

The Russian government decided in January 2014 to sell its stake in OJSC INTER RAO UES and JSC Arkhang elsk Trawl Fleet (ATF), $13.76 \%$ and $100 \%$, respectively.

The former transaction ( $\mathrm{Rb} 18,8 \mathrm{bn}$ worth) can rather be characterized as quasi-privatization deal, because the buyer was state-controlled OJSC Rosneftegaz embarking on diversification of its business. At the same time, a provision in the effective (and the previous) privatization program was executed de facto, which reads that until 2015 Rosneftegaz may act as investor with regard to energy companies whose shares are planned for privatization on conditions that a program on financing of such transactions is available and provides the use of dividends on the companies' shares held by joint-stock company in question.

The latter transaction ( $R b 2,2$ bn worth), whose dealmaker was selected Gazprombank late in 2011, can be exemplified as the first unconventional approach as part of the modern privatization process.

The specific features of the transaction is a shareholder agreement between the new owner (LLC Virma) of JSC Arkhangelsk Trawl Fleet (ATF) and the regional government authorities which now have the opportunity to influence further development of the ATF through a free transfer of one share in the company (with a seat reserved on the Board of Directors) and mutual approval of critical decisions concerning the functionality of the region.

Basically, the entering into the shareholder agreement while selling JSC Arkhangelsk Trawl Fleet can be viewed as new method of striking an adequate balance of interests between the state (represented by the Arkhangelsk Region) and the new owner in terms of social commitments and enhancing business effectiveness. However, further monitoring of company's development is needed for a certain period of time in order to be able to exemplify the ATF case as best practice deserved to be followed.

Regarding the traditional privatization toolkit, the largest transaction using the toolkit was Rosimuschestvoheld (the Federal Agency for State Property Management) auction of the federally-held $(100 \%)$ shares in OJSC Leninsky Put' Experimantal Stub Farm (the Krasnodar Territory), Rb 1563m worth. All other transac- 
Table 1

THE COMPOSITION OF FEDERAL BUDGET PROPERTY-RELATED REVENUES FROM VARIOUS SOURCES IN 2000-2014

\begin{tabular}{|c|c|c|c|c|c|c|}
\hline \multirow[t]{2}{*}{ Year } & \multicolumn{2}{|c|}{$\begin{array}{l}\text { Gross revenues from } \\
\text { government property privati- } \\
\text { zation/sale and utilization }\end{array}$} & \multicolumn{2}{|c|}{$\begin{array}{l}\text { Revenues from property privatiza- } \\
\text { tion/sale (nonrenewable sources) }\end{array}$} & \multicolumn{2}{|c|}{$\begin{array}{l}\text { Revenues from government prop- } \\
\text { erty utilization (renewable sources) }\end{array}$} \\
\hline & millions of rubles & $\%$ of total & millions of rubles & $\%$ of total & millions of rubles & $\%$ of total \\
\hline 2000 & 50412,3 & 100.0 & 27167,8 & 53.9 & 23244,5 & 46.1 \\
\hline 2001 & 39549,8 & 100.0 & 10307,9 & 26.1 & 29241,9 & 73.9 \\
\hline 2002 & 46811,3 & 100.0 & 10448,9 & 22.3 & 36362,4 & 77.7 \\
\hline 2003 & 135338,7 & 100.0 & 94077,6 & 69.5 & 41261,1 & 30.5 \\
\hline 2004 & 120798,0 & 100.0 & 70548,1 & 58.4 & 50249,9 & 41.6 \\
\hline 2005 & 97357,4 & 100.0 & 41254,2 & 42.4 & 56103,2 & 57.6 \\
\hline 2006 & 93899,8 & 100.0 & 24726,4 & 26.3 & 69173,4 & 73.7 \\
\hline 2007 & 105761,25 & 100.0 & 25429,4 & 24.0 & 80331,85 & 76.0 \\
\hline 2008 & 88661,7 & 100.0 & 12395,0 & 14.0 & 76266,7 & 86.0 \\
\hline 2009 & 36393,7 & 100.0 & 4544,1 & 12.5 & 31849,6 & 87.5 \\
\hline 2010 & 88406,4 & 100.0 & 18677,6 & 21.1 & 69728,8 & 78.9 \\
\hline 2011 & 240964,1 & 100.0 & 136660,1 & 56.7 & 104304,0 & 43.3 \\
\hline 2012 & $\begin{array}{l}309943,2 / \\
469243,2^{*}\end{array}$ & 100.0 & $\begin{array}{c}80978,7 / \\
240278,7^{*}\end{array}$ & $\begin{array}{l}26.1 / \\
51.2^{*}\end{array}$ & 228964,5 & $\begin{array}{l}73.9 / \\
48.8^{*}\end{array}$ \\
\hline 2013 & 209114,85 & 100.0 & 55288,6 & 26.4 & 153826,25 & 73.6 \\
\hline 2014 & 282324,1 & 100.0 & 41154,65 & 14.6 & 241169,45 & 85.4 \\
\hline
\end{tabular}

* inclusive of the resources which the Russian Central Bank received from selling Sberbank's shares (Rb 159,3bn), thus probably overestimating a bit the gross percentage of nonrenewable sources, given that the budget received the foregoing resources less their book value and the sum of costs relating to the sale the shares in question. Consequently, the share of renewable sources is probably slightly undervalued.

Source: the federal laws on the execution of the federal budget in 2000-2013; the Federal budget execution report as of 1 January 2015 (monthly), www.roskazna.ru; the calculations made by the authors.

tions were equal or less than $\mathrm{Rb} 500 \mathrm{~m}$ worth, including the sales held by a non-government seller, OJSC Auction House of the Russian Federation (AHRF), whose business saw a marked decline. The company sold last year six blocks of shares $\mathrm{Rb} 923,3 \mathrm{~m}$ worth ${ }^{1}$, twice as less as in 2013 (15 sales Rb 1,97bn worth).

The preparation for privatization transactions regarding other largest assets listed in the effective privatization program varies in stages, while details on most of them are not quite clear. For instance, contractors of a public contract for organizing and undertaking on behalf of the Russian Federation transactions of selling federally-held shares were selected for four of the seven companies in which the state is to cease to hold a stake (shareholding in the chartered capital) in 2014-2016.

The measures taken by Rosimuschestvo and its territorial branches in 2014 - which included the preparation for privatization of new assets, enhancing the sale system, the work with potential investors, the information support to privatization - resulted in improved quality of lots put out for tender, with a better access to the information about such lots.

Thorough presale and marketing preparation of assets to be privatized (despite the decline in sales of shares (shareholding in chartered capitals) amid

1 www.rosim.ru, 24.12.2014. the worsening of economic situation and investment downturn) allowed extra revenues from privatization to be generated.

The gains from selling a shareholding (a stake in the chartered capital) in business entities were running at $\mathrm{Rb} 8,05 \mathrm{bn}$ (including the revenues expected in Q1 2015), 2.7 times the target amount (net of largest sales), drawing on the forecast for revenues ( $\mathrm{Rb} 3 \mathrm{bn}$ annually within a period of 2014-2016) made in the privatization program. According to the monthly Federal budget execution progress report as of 1 January 2015 (concerning sources of internal financing of the deficit) available at the official website of the Federal Treasury, the revenues from selling of a shareholding and other forms of government's shareholding in the chartered capital were running at $\mathrm{Rb} 29,7 \mathrm{bn}$, thereby showing a more than $14 \%$ outrun of budget appropriations in 2014.

The total volume of federal budget revenues from federal property privatization (sale) and utilization increased 35\% year-over-year in 2014 (Table 1). The amount of the revenues in absolute terms ( $\mathrm{Rb} 282,3 \mathrm{bn}$ ) has since earlier in the 2000s become the second after the maximum value reached in 2012 , outrunning by $17 \%$ the value seen in 2011.

The ratio of nonrenewable sources to renewable sources in the structure of total revenues from 
government property privatization (sale) and utilization was almost equal to the values seen during the crisis in 2008-2009, when the privatization process was seriously hampered by external conditions and no major transactions took place.

Compared with 2013, the share of nonrenewable sources in the structure of total revenues from government property privatization (sale) and utilization in 2014 almost halved to $14.6 \%$, whereas the share of revenues from government property utilization increased almost to $85.4 \%$ from $73.6 \%$ in 2014 . This result has been the highest in absolute value throughout the entire period since the 2000s began, whereas revenues from privatization and sale of property/ assets appeared to be approximately by one fourth less compared with those in 2013, although they outran the values reached in the period between 2006 and 2010.

The process of integration of state-owned assets continued in 2014. Respective decisions were made on the terms of privatization of 11 FSUEs and the shares in 47 joint-stock companies, while measures were taken to establish 16 vertically-integrated companies (VICS), four of which (OJSC Concern Granit Electron, Rosgeologia, Tactical Missiles Corporation JSC, and ROSATOM state nuclear corporation) were completed.

Regarding the government involvement in the economy, the milestone event of the past year was the court ruling reclaiming AFC Sistema's majority stake in Bashneft (71.6\% of shareholding) to the benefit of the federal government. The ruling was issued on the ground of violations committed in the course of privatization, which arose from the disagreements between the federal government and the constituent territories of the Russian Federation on the division of the entire government properties at the initial stage of the ownership reform and the powers arising under it. The transfer of the shareholding in Bashneft directly to the federal government (represented by Rosimuschestvo offers the latter a wide spectrum of options regarding the future of the company which remained a regionallevel company throughout the entire period of business operations.

Of greater importance for the entire property relationships is the approval by the Russian Government Executive Order of 15 April 2014 No. 327 of a new Federal Property Management State Program (SP) instead of the former SP with the same title which had been in effect only about 14 months $^{1}$. The substitution has no visible reasons though.

1 For more details on the 2013 state program see Malginov G., Radygin A. The state of Public sector and privatization. Section 6.1// Russian economy in 2012. Trends and outlooks (Issue 34). M. IEP. 2013. P. $367-400$.
The qualitatively expressed target indicators for the implementation of the State Program Federal Property Management until 2018 are, by and large, equal to those of the 2013 Program. As a reminder, they refer to such indices as share of federal property units (by category) for whom the target function was set (unitary enterprises, business entities with state participation, agencies, treasury units), rates of reducing the number of property units by principal category (for enterprises and joint-stock companies as a percent annually, for property units and set-aside treasury land plots - as a percent of the 2012 values, except prohibited or controlled items), indices showing the dynamics of technological development of the processes of federal property management, and some others. At the same time, unlike the 2013 state program, the new document contains no target indicators that can be achieved if extra resources are allocated.

A successful implementation of the privatization forecast plan depends generally on the macroeconomic situation and specifically on developments in the stock market.

Earlier in December last year, when the federal budget for 2015-2017 was adopted, the revenues from government property privatization were projected $\mathrm{Rb} 158,5 \mathrm{bn}$ in 2015, and $\mathrm{Rb} 99,9 \mathrm{bn}$ in 2016, as seen from the contents of accompanying documents to the respective government draft bill².

The update, triggered by serious changes in the macroeconomic situation, to the effective federal budget stipulated in the federal law of 20 April 2015 No. 93-FZ, affected this aspect of the budget process too.

It was specified in the explanatory note to the draft bill submitted to the State Duma that revenues from federal property privatization are still considered as stand-alone source of financing of the federal budget deficit.

It is specified in the explanatory note to the draft bill submitted to the State Duma that revenues from federal property privatization are still considered as stand-alone source of financing of the federal budget deficit. However, drastic cuts, to Rb $15,0 b n$ from $\mathrm{Rb} 158,5 \mathrm{bn}$, of revenues from federal property privatization are envisaged in 2015. Of course, a reduction by an order of magnitude in revenues from federal property privatization will make their role strictly supplementary in financing of federal budget deficit com-

2 It is worthwhile noting in this context that neither does the Federal Law of the federal budget for 2015 and the planning period of 2016 and 2017 of 1 December 2014, No. 384-FZ contain any data on the amount of revenues from selling federally-held shares and other forms of shareholding in the chartered capital, nor they are listed among sources of budget deficit financing. 
pared to the suggested spending of the resources from the Reserve Fund.

The anticipated volume of revenues from selling of government's shareholding in large investmentattractive companies and the volume of federal budget revenues from federal property privatization, not including the value of shareholding in largest companies set by the Forecast Plan (Program) of Federal Property Privatization and the Guidelines of Federal Property Privatization for 2014-2016, are mentioned as a reason for the specified $\mathrm{Rb} 15 \mathrm{bn}$ worth federal budget revenues from selling of a shareholding and other forms of shareholding in the chartered capital.

While the effective privatization program specifies as little as $\mathrm{Rb} 3,0 \mathrm{bn}$ annual amount of federal budget revenues from federal property privatization, not including the value of shareholding in largest companies, there is no forecast as such for principal revenues from privatization through selling of a shareholding in largest investment-attractive companies, if the Russian government makes certain decisions.

Regarding revenues from government property utilization, the amendments to the federal budget consider the decline of more than $\mathrm{Rb} 53 \mathrm{bn}$ in the amount of dividends on government shareholding. This resulted basically from nonpayment of dividends by OJSC Rosneftegaz from selling of the shares in OJSC Rosneft (Rb 100,0bn), as well as the reduction of dividends on OJSC Gazprom's shares (down Rb 11,5bn). More than a half of the budget losses from these sources must be offset by a $\mathrm{Rb} 58,4 \mathrm{bn}$ growth in dividends on other government shareholding. Regarding this part, however, the forecast for budget revenues seems not to be quite substantiated, because the decline in total volume of 2015 federal budget revenues from dividends compared with 2014 (not including the revenues from selling of Rosneft's shares) was explicitly specified in the documents attached to the draft bill on the federal budget in 2015-2017 which was submitted to the State Duma in the fall last year.

The Federal Property Management State Program (SP) adopted by the Russian Government Executive Order of 15 April 2014 No. 327 is among many of the federal budget expenditure items to be updated. Total budget appropriations in 2015 to ensure the implementation of the Program is to be cut by $6.7 \%$ (or about $\mathrm{Rb} 1,9 \mathrm{bn}$ ). However, volumes of financing will be cut unevenly according to the sub-programs of the foregoing SP: while the allocations for the Sub-Program on "Enhancing the Effectiveness of Federal Property Management and Privatization" will be cut $10.4 \%$, the allocations for the Sub-Program "Administration of State Material Reserve" will be cut as little as $5.8 \%$.
Basically, the 2014 results allow one to hope that the targets will be achieved, given the amount of federal budget revenues from privatization specified in the effective privatization program, i.e. net of largest sales.

The results of Q1 2015 support this. During this period, according to Rosimuschestvo, 23 blocks of shares were sold at a total of $\mathrm{Rb} 699,9 \mathrm{~m}$. The largest (more than $\mathrm{Rb} 300 \mathrm{~m}$ ) was the sale of the Labinsky Pedigree Poultry Farm in the Krasnodar Territory, while two road service enterprises in Sakha (Yakutia) were sold at more than $\mathrm{Rb} 100 \mathrm{~m}^{1}$ According to the monthly Federal budget execution report as of 1 January 2015 (concerning sources of internal financing of the deficit) available at the official website of the Federal Treasury, the revenues from selling a shareholding and other forms of government's shareholding in the chartered capital were running at $\mathrm{Rb} 345,3 \mathrm{~m}$.

By far less clear are horizons of transactions with largest assets which, having a visible effect on the execution of budgetary assignments, require, most of all, that the real state of investment and capital flow are considered and businesses have long-term incentives for the development of important segments of the Russian economy.

It was clear before this document was issued that certain questions would raise about the government having ceased to hold, or having cut, its interest in the chartered capital of many companies listed in the forecast plan (program) of privatization in 2014$2016^{2}$.

This is heavily supported by the developments that took place last year and early in 2015. It is sufficient to mention OJSC Rosneft, for which a government executive order issued as early as November 2014, i.e. before the budget update, set the condition under which its shares may be sold at a lower than market price based on the report on valuation of shares at market prices prepared by an independent appraiser, and not less the price of Rosneft IPO in 2006. With respect to OJSC Rostelecom, the structure and methods of selling federally-held shares cannot be considered until a systemic project on integrated communication network is completed. The same goes for the exclusion of OJSC Rosnano, a former public corporation, from the forecast plan of privatization in 2014-2016, which was most significant of the amendments made to the effective privatization program by the Russian Government Executive Order of 17 April 2015 No. 682-p.

1 www.rosim.ru, 15.04.2015.

2 For more details see Malginov G., Radygin A. Public sector and privatization. Section 6.1 // Russian economy in 2013. Trends and outlooks (Issue 35). M., IEP. 2014, P. p. 365-395. 